\title{
A Comparative Kinetic Study of Silver(I)-Catalyzed Oxidations of Alanine and Valine by Platinum (IV) in Perchloric and Sulfuric Acids Solutions
}

\author{
Ahmed Fawzy ${ }^{1,2, ~}{ }^{*}$, Ishaq A. Zaafarany ${ }^{1}$, Fahd A. Tirkistani ${ }^{1}$, Ismail Althagafi ${ }^{1}$, Jabir Alfahemi ${ }^{1}$ \\ ${ }^{1}$ Chemistry Department, Faculty of Applied Science, Umm Al-Qura University, Makkah, Saudi Arabia \\ ${ }^{2}$ Chemistry Department, Faculty of Science, Assiut University, Assiut, Egypt
}

Email address:

afsaad13@yahoo.com (A. Fawzy), iazaafarany@uqu.edu.sa (I. A. Zaafarany),drfahd999@gmail.com (F. A. Tirkistani), iithagafi@uqu.edu.sa (I. Althagafi),jhfahemi@uqu.edu.sa (J. Alfahemi)

${ }^{*}$ Corresponding author

\section{To cite this article:}

Ahmed Fawzy, Ishaq A. Zaafarany, Fahd A. Tirkistani, Ismail Althagafi, Jabir Alfahemi. A Comparative Kinetic Study of Silver(I)-Catalyzed Oxidations of Alanine and Valine by Platinum (IV) in Perchloric and Sulfuric Acids Solutions. American Journal of Physical Chemistry.

Vol. 5, No. 3, 2016, pp. 65-73. doi: 10.11648/j.ajpc.20160503.13

Received: April 17, 2016; Accepted: April 25, 2016; Published: May 10, 2016

\begin{abstract}
The kinetics of oxidations of two aliphatic $\alpha$-amino acids (AA), namely, alanine and valine by platinum (IV) has been investigated spectrophotometrically in perchloric and sulfuric acids solutions in the presence of silver (I) catalyst at a constant ionic strength of $1.0 \mathrm{~mol} \mathrm{dm}^{-3}$ and at $25^{\circ} \mathrm{C}$. The reactions were very slow to be measured in the absence of the catalyst. The reactions in both acids showed a first order dependence on both $\left[\mathrm{Pt}^{\mathrm{IV}}\right]$ and $\left[\mathrm{Ag}^{\mathrm{I}}\right]$, and less than unit order dependences with respect to both $[\mathrm{AA}]$ and $\left[\mathrm{H}^{+}\right]$. Increasing ionic strength was found to decrease the oxidation rates. Under comparable experimental conditions, the oxidation rates of alanine and valine in perchloric acid solutions were found to be about five times higher than those obtained in sulfuric acid solutions and the oxidation rates of alanine in both acids were found to be higher than those recorded with respect to valine. A plausible oxidations mechanism has been proposed and the rate law expression has been derived. Both spectral and kinetic evidences revealed formation of 1:1 intermediate complexes between $\mathrm{AA}$ and $\mathrm{Ag}^{\mathrm{I}}$ in both acids before the rate-controlling step. Then the formed complexes react with the oxidant $\left(\mathrm{Pt}^{\mathrm{IV}}\right)$ by an inner-sphere mechanism to give rise to the oxidation products of the amino acids which were identified as the corresponding aldehyde, ammonium ion and carbon dioxide. The activation parameters of the second order rate constants were evaluated and discussed.
\end{abstract}

Keywords: $\alpha$-Amino Acids, Platinum (IV), Kinetics, Mechanism, Oxidation, Silver (I) Catalyst

\section{Introduction}

Alanine and valine (their structure shown below) are aliphatic $\alpha$-amino acids that are used in the biosynthesis of proteins. Alanine is a non-essential amino acid in humans which synthesized in the human body from pyruvate and branched chain amino acids such as valine, leucine, and isoleucine. Valine is essential in humans, hence it must be ingested, usually as a component of proteins. Alanine occurs in bacterial cell walls and in some peptide antibiotics. Alanine plays a key role in glucose-alanine cycle between tissues and liver. The glucose-alanine cycle enables pyruvate and glutamate to be removed from the muscle and find their way to the liver. Valine is needed for muscle metabolism and coordination, tissue repair and for the maintenance of proper nitrogen balance in the body. In sickle-cell disease, valine substitutes for the hydrophilic amino acid glutamic acid in $\beta$ globin. Oxidation of amino acids is considered as a significant field of organic chemistry due to its bearing on the mechanism of amino acid metabolism. Kinetics of oxidation of amino acids by various oxidants in different media has been studied earlier [1-23], and they often undergo oxidative decarboxylation and deamination. 
<smiles>C[C@H](N)C(=O)O</smiles>

Alanine<smiles>CC(C)[C@H](N)C(=O)O</smiles>

Valine

It has been noted that transition metal ions in the higher oxidation state can usually be stabilized by chelation with suitable complex agents, so that metal complexes formed would be good oxidants in acidic or alkaline media under appropriate conditions. Platinum (IV) complexes have increased interest in the last decades due to their remarkable anticancer properties [24-27]. Kinetic studies on the oxidation of inorganic and organic substrates using one of the platinum (IV) complexes such as hexachloroplatinate (IV) complex, $\left[\mathrm{PtCl}_{6}\right]^{2-}$, are scarce and limited to a few cases [15$21,28-31]$, in which $\left[\mathrm{PtCl}_{6}\right]^{2-}$ may behave as one or two electron oxidant, depending upon the substrate and experimental conditions. The knowledge of the reactivity of platinum (IV) compounds towards their reduction by potential bioreductants such as alanine and valine may be important for understanding the mechanism of where antitumor activity as well as for designing new compounds with the least side effect.

Transition metal ions have been widely employed as homogenous catalysts for oxidation of organic and inorganic substrates [12-22] by different reaction pathways such as formation of complexes with the reactants, oxidation of a substrate, or the formation of free radicals [32]. Kinetic investigations on the oxidation of amino acids catalyzed by different metal ions are an important field of chemistry due to the role played by metals in biological systems.

Literature survey reveals that there are no reports about the kinetics of oxidations of alanine and valine by platinum (IV). In view of the above mentioned arguments, we have carried out a detailed study on the kinetics and mechanism of oxidations of these amino acids by biologically active platinum (IV) complex in different acid media, namely, perchloric and sulfuric acids solutions, in the presence of silver (I) catalyst. This work aims to study the selectivity of the studied amino acids towards platinum (IV) in acid media, to check the catalytic efficiency of $\mathrm{Ag}^{\mathrm{I}}$ catalyst, and to elucidate a plausible reactions mechanism.

\section{Experimental}

\subsection{Materials}

Reagent grade chemicals and doubly distilled water were used throughout the work. A stock solutions of the investigated $\alpha$-amino acids were prepared by dissolving the amino acids samples (E. Merck) in bidistilled water. Chloroplatinic acid solution (Johnson Matthey) was used without further purification. Required solution of the oxidant was freshly prepared before each experiment by proper dilution of its original solution which is standardized spectrophotometrically [33]. The solution was stored in a

bottle away from light and re-standardized periodically. Sodium pechlorate and sodium sulfate were used to vary the ionic strength in both perchloric and sulfuric acids solutions, respectively.

\subsection{Kinetic Measurements}

All kinetic investigations were conducted under pseudofirst-order conditions where the amino acid was present in a large excess over that of platinum (IV). The ionic strength, $I$, of the reactions mixtures was adjusted to 1.0 moldm $^{-3}$. The reactions temperature $\left(25^{\circ} \mathrm{C}\right)$ was controlled within $\pm 0.1^{\circ} \mathrm{C}$ unless stated otherwise. The courses of the reactions were followed spectrophotometrically by monitoring the decrease in the absorbance of $\mathrm{Pt}^{\mathrm{IV}}$ at $\lambda=261 \mathrm{~nm}$, its absorption maximum, as a function of time using Shimadzu UV-VISNIR-3600 double-beam spectrophotometer with a cell compartment kept at constant temperature. The applicability of Beer's law was verified at $261 \mathrm{~nm}$ under the reaction conditions. The molar extinction coefficient, $\varepsilon$, was determined, $\varepsilon=(1.32 \pm 0.04) \times 10^{4} \mathrm{dm}^{3} \mathrm{~mol}^{-1} \mathrm{~cm}^{-1}$, and was found to be in a good agreement with that reported previously [28]. In addition, there is no interference from other reagents at this wavelength. It was observed that the oxidation reactions were very slow to be measured in the absence of silver (I) catalyst. The pseudo-first order rate constant values of the catalyzed reactions $\left(k_{\mathrm{C}}\right)$ were obtained from the linear portion of $\ln$ (absorbance) versus time plots, which were the average of at least two independent kinetics runs and were reproducible to within $\pm 2-4 \%$.

\section{Results}

\subsection{Time-Resolved Spectra}

Time-resolved spectra during the silver (I) catalyzedoxidations of alanine and valine by platinum (IV) in perchloric and sulfuric acids solutions are shown in Figure 1 (a) - (d), respectively. The scanned spectra indicate gradual disappearance of the $\mathrm{Pt}^{\mathrm{IV}}$ absorption band with time as a result of its reduction. A hyposchromic shift in the $\mathrm{Pt}^{\mathrm{IV}}$ band of about $6 \mathrm{~nm}$ from 261 to $255 \mathrm{~nm}$ as well as two isosbestic points located at 245 and $280 \mathrm{~nm}$ are apparent in the spectra.

\subsection{Stoichiometry and Product Identification}

Different reactions mixtures with different sets of reactants containing various amounts of $\mathrm{Pt}^{\mathrm{IV}}$ and $\mathrm{AA}$ in both acids solutions at fixed acidity, ionic strength, and temperature were allowed to react for about $24 \mathrm{~h}$. After completion of the reactions, the unreacted $\left[\mathrm{Pt}^{\mathrm{IV}}\right]$ was assayed spectrophotometrically. Results indicated that one mole of the amino acid consumed one mole of $\mathrm{Pt}^{\mathrm{IV}}$ in the predominant reactions, as represented in the following stoichiometric equation:

$$
\underbrace{\mathrm{O}}_{\mathrm{NH}_{2}} \mathrm{OH}+\left[\mathrm{PrCl}_{6}\right]^{2-}+\mathrm{H}_{2} \mathrm{O} \stackrel{\mathrm{Ag}^{\prime}}{\longrightarrow} \prod_{\mathrm{O}}^{\mathrm{R}} \prod^{\mathrm{H}}+\left[\mathrm{PtCl}_{4}\right]^{2{ }^{2}}+2 \mathrm{Cl}^{2}+\mathrm{CO}_{2}+\mathrm{NH}_{4}^{+}+\mathrm{H}^{+}
$$


where $\mathrm{R}=\mathrm{CH}_{3}$ for alanine, and $\mathrm{R}=\mathrm{CH}\left(\mathrm{CH}_{3}\right)_{2}$ for valine.

The corresponding aldehydes were identified as reported earlier $[34,35]$. The byproductswere identified as ammonia by Nessler's reagent and carbon dioxide by lime water. On
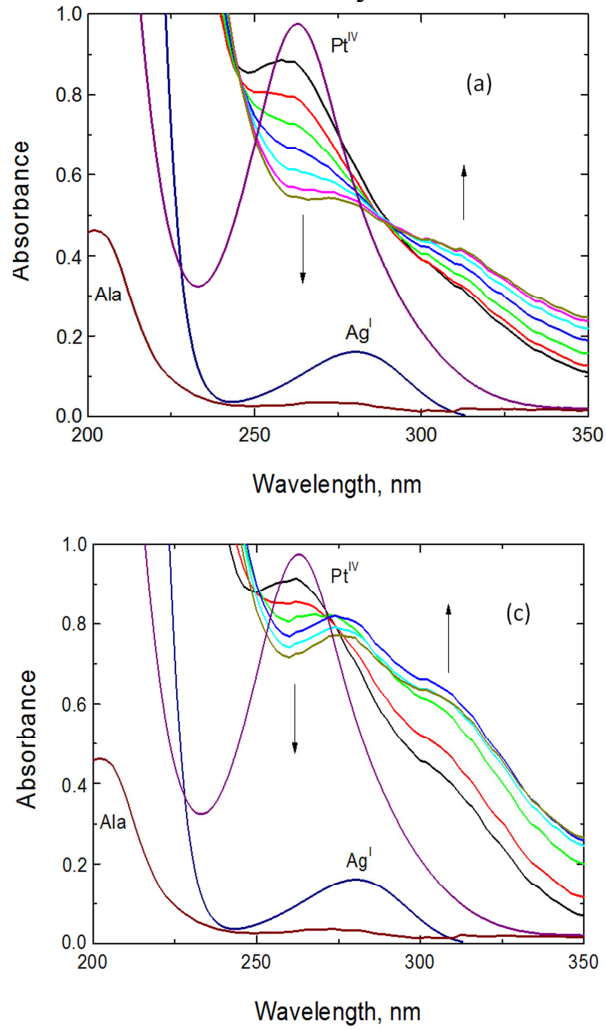

the other hand, the formation of $\left[\mathrm{Pt}^{\mathrm{II}} \mathrm{Cl}_{4}\right]^{2-}$ was confirmed $[15-21,31]$ by the observed black precipitate of platinum (II) hydroxide on addition of alkali to the reactions mixtures, according to the reaction, $\left[\mathrm{PtCl}_{4}\right]^{2-}+2 \mathrm{OH}^{-}=\mathrm{Pt}(\mathrm{OH})_{2}+4 \mathrm{Cl}^{-}$.
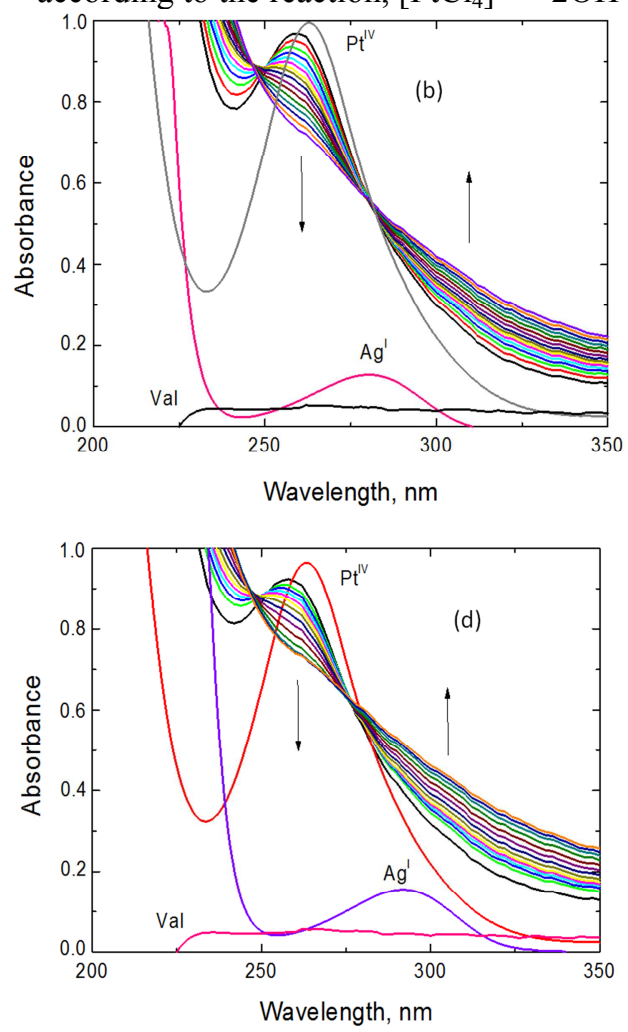

Figure 1. Time-resolved spectra during silver (I)-catalyzed oxidations of alanine and valine by platinum(IV) in perchloric acid, (a) \& (b), and sulfuric acid, (c) $\&(d)$, respectively. $[\mathrm{AA}]=6.0 \times 10^{-3},\left[\mathrm{Pt}^{\mathrm{IV}}\right]=8.0 \times 10^{-5},\left[\mathrm{H}^{+}\right]=0.5,\left[\mathrm{Ag}^{\mathrm{I}}\right]=1.0 \times 10^{-5}$ and $\mathrm{I}=1.0 \mathrm{~mol} \mathrm{dm}^{-3}$ at $25^{\circ} \mathrm{C}$.

Table 1. Effect of variation of $\left[P t^{I V}\right],[A A],\left[H^{+}\right],\left[\mathrm{Ag}^{I}\right]$ and ionic strength, I, on the observed first order rate constant (kC) in the silver (I)-catalyzed oxidations of alanine and valine by platinum(IV) in perchloric and sulfuric acids solutions at $25^{\circ} \mathrm{C}$. Experimental Error $\pm 3 \%$.

\begin{tabular}{|c|c|c|c|c|c|c|c|c|}
\hline \multirow{3}{*}{$\begin{array}{l}10^{5}[\mathrm{HCP}] \\
\left(\mathrm{mol} \mathrm{dm}^{-3}\right)\end{array}$} & \multirow{3}{*}{$\begin{array}{l}10^{3}[\mathrm{AA}] \\
\left(\mathrm{mol} \mathrm{dm^{-3 }}\right)\end{array}$} & \multirow{3}{*}{$\begin{array}{l}{\left[\mathrm{H}^{+}\right]} \\
\left.(\mathrm{mol} \mathrm{dm})^{-3}\right)\end{array}$} & \multirow{3}{*}{$\begin{array}{l}10^{5}\left[\mathrm{Ag}^{\mathrm{I}}\right] \\
\left(\mathrm{mol} \mathrm{dm} \mathrm{dm}^{-3}\right)\end{array}$} & \multirow{3}{*}{$\begin{array}{l}I \\
\left(\mathrm{~mol} \mathrm{dm}^{-3}\right)\end{array}$} & \multicolumn{4}{|c|}{$10^{5} k_{\mathrm{C}}\left(\mathrm{s}^{-1}\right)$} \\
\hline & & & & & \multicolumn{2}{|c|}{ Perchloric } & \multicolumn{2}{|l|}{ Sulfuric } \\
\hline & & & & & Alanine & Valine & Alanine & Valine \\
\hline 2.0 & 6.0 & 0.5 & 1.0 & 1.0 & 161.2 & 108.7 & 32.0 & 27.7 \\
\hline 4.0 & 6.0 & 0.5 & 1.0 & 1.0 & 159.7 & 111.2 & 33.8 & 25.7 \\
\hline 6.0 & 6.0 & 0.5 & 1.0 & 1.0 & 158.8 & 109.7 & 31.4 & 26.5 \\
\hline 8.0 & 6.0 & 0.5 & 1.0 & 1.0 & 156.9 & 110.2 & 29.9 & 26.0 \\
\hline 10.0 & 6.0 & 0.5 & 1.0 & 1.0 & 157.0 & 110.9 & 30.4 & 26.6 \\
\hline 8.0 & 2.0 & 0.5 & 1.0 & 1.0 & 85.0 & 55.6 & 14.3 & 12 \\
\hline 8.0 & 4.0 & 0.5 & 1.0 & 1.0 & 122.3 & 80.1 & 23.2 & 20 \\
\hline 8.0 & 6.0 & 0.5 & 1.0 & 1.0 & 158.8 & 109.7 & 31.4 & 26.5 \\
\hline 8.0 & 8.0 & 0.5 & 1.0 & 1.0 & 195.4 & 133.8 & 39.0 & 33.9 \\
\hline 8.0 & 10.0 & 0.5 & 1.0 & 1.0 & 230.5 & 157.5 & 47.4 & 41.7 \\
\hline 8.0 & 6.0 & 0.1 & 1.0 & 1.0 & 59.2 & 39.1 & 11.4 & 9.2 \\
\hline 8.0 & 6.0 & 0.3 & 1.0 & 1.0 & 117.0 & 78.2 & 24.7 & 19.0 \\
\hline 8.0 & 6.0 & 0.5 & 1.0 & 1.0 & 158.8 & 109.7 & 31.4 & 26.5 \\
\hline 8.0 & 6.0 & 0.7 & 1.0 & 1.0 & 210.4 & 135.7 & 41.0 & 34.3 \\
\hline 8.0 & 6.0 & 0.9 & 1.0 & 1.0 & 248.9 & 168.0 & 51.4 & 42.1 \\
\hline 8.0 & 6.0 & 0.5 & 0.4 & 1.0 & 55.3 & 34.5 & 12.3 & 10.4 \\
\hline 8.0 & 6.0 & 0.5 & 0.7 & 1.0 & 105.2 & 65.0 & 21.0 & 17.2 \\
\hline 8.0 & 6.0 & 0.5 & 1.0 & 1.0 & 158.6 & 109.7 & 31.4 & 26.5 \\
\hline 8.0 & 6.0 & 0.5 & 1.5 & 1.0 & 231.7 & 145.2 & 44.0 & 37.3 \\
\hline 8.0 & 6.0 & 0.5 & 2.0 & 1.0 & 279.4 & 180.7 & 56.1 & 49.1 \\
\hline 8.0 & 6.0 & 0.5 & 1.0 & 1.0 & 158.8 & 109.7 & 31.4 & 26.5 \\
\hline 8.0 & 6.0 & 0.5 & 1.0 & 1.5 & 153.4 & 105.3 & 29.2 & 23.1 \\
\hline 8.0 & 6.0 & 0.5 & 1.0 & 2.0 & 149.6 & 99.7 & 26.3 & 19.7 \\
\hline 8.0 & 6.0 & 0.5 & 1.0 & 2.5 & 145.9 & 95.1 & 24.9 & 18.2 \\
\hline 8.0 & 6.0 & 0.5 & 1.0 & 3.0 & 142.7 & 91.2 & 21.7 & 16.7 \\
\hline
\end{tabular}




\subsection{Orders of the Reactions}

Double logarithmic plots were used to determine the orders with respect to the reactants. The concentration of the particular species being examined was varied while the concentrations of the other species were held fixed.

The concentration of the oxidant, platinum (IV), was varied in both acids in the range of $2.0 \times 10^{-5}$ to $10.0 \times 10^{-5} \mathrm{~mol}$ $\mathrm{dm}^{-3}$ at constant $[\mathrm{AA}],\left[\mathrm{Ag}^{\mathrm{I}}\right],\left[\mathrm{H}^{+}\right]$, ionic strength and temperature. The non-variation in the observed first order rate constants at various concentrations of $\mathrm{Pt}^{\mathrm{IV}}$ (Table 1) indicates that the order with respect to the oxidant is confirmed to be one.

The observed first order rate constant $\left(k_{\mathrm{C}}\right)$ was determined at different initial concentrations of the reductantsalanine and valine keeping all other reactants concentration constant. The results showed that the rate constants in both acids increased with increasing the amino acids concentrations as listed in Table 1 . The plots of $k_{\mathrm{C}}$ versus [AA] in both acids were found to be linear with positive intercepts confirming less than unit order dependences with respect to the amino acids (Figure 2).

The rates of the reactions in both acids were measured at constant concentrations of amino acids, $\mathrm{Pt}^{\mathrm{IV}}, \mathrm{Ag}^{\mathrm{I}}$, ionic

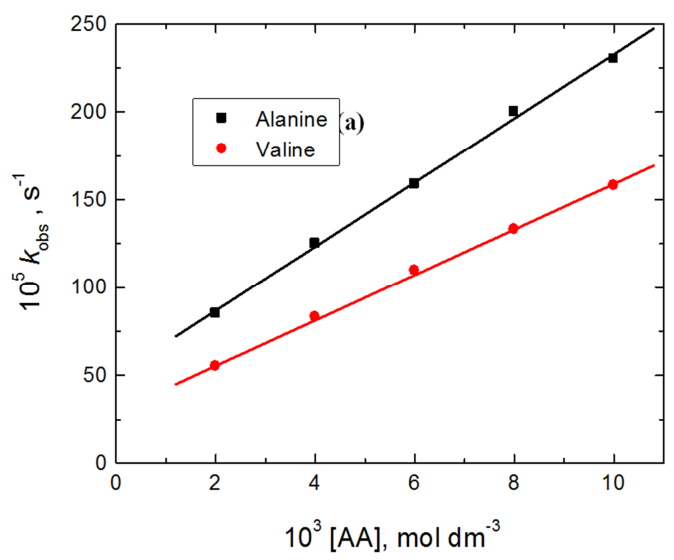

strength and temperature but with various $\left[\mathrm{H}^{+}\right](0.1-0.9 \mathrm{~mol}$ $\left.\mathrm{dm}^{-3}\right)$. The rates were found to increase as $\left[\mathrm{H}^{+}\right]$increased with less than unit orders as found from the plots of $\log k_{\mathrm{C}}$ versus $\log \left[\mathrm{H}^{+}\right]$(Figure 3).

The oxidation rates were measured with various concentrations of silver (I) catalyst in the concentration range of $(0.4-2.0) \times 10^{-5}$ moldm $^{-3}$ at constant other variables. The oxidation rates were found to increase with increasing $\left[\mathrm{Ag}^{\mathrm{I}}\right]$ as listed in Table 1. The order with respect to $\left[\mathrm{Ag}^{\mathrm{I}}\right]$ was approximately unity in both acids as found from the plots of $\log k_{\mathrm{C}}$ versus $\log \left[\mathrm{Ag}^{\mathrm{I}}\right]$ as illustrated in Figure 4.

\subsection{Effect of Ionic Strength}

The effect of ionic strength on the oxidation rates was investigated by the addition of sodium perchlorate in case of perchloric acid and sodium sulfate in case of sulfuric acid to the reactions media at constant concentrations of $\mathrm{AA}, \mathrm{Pt}^{\mathrm{IV}}$ and $\mathrm{Ag}^{\mathrm{I}}$, and at constant $\mathrm{pH}$ and temperature. The results showed that the rate constants decreased with increasing the ionic strength of the media, and the Debye-Hückel plots were found to be linear with negative slopes as shown in Figure 5.

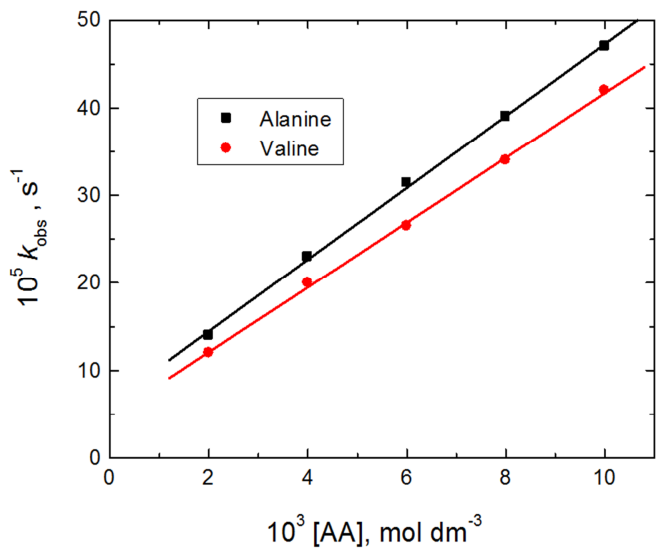

Figure 2. Plots of the observed first order rate constant $\left(k_{C}\right)$ versus [AA] in the silver (I)-catalyzed oxidations of alanine and valine by platinum (IV) in perchloric and sulfuric acids solutions. $\left[\mathrm{Pt}^{I V}\right]=8.0 \times 10^{-5},\left[\mathrm{H}^{+}\right]=0.5,\left[\mathrm{Ag}^{I}\right]=1.0 \times 10^{-5}$ and $\mathrm{I}=1.0 \mathrm{~mol} \mathrm{dm^{-3 }}$ at $25^{\circ} \mathrm{C}$.
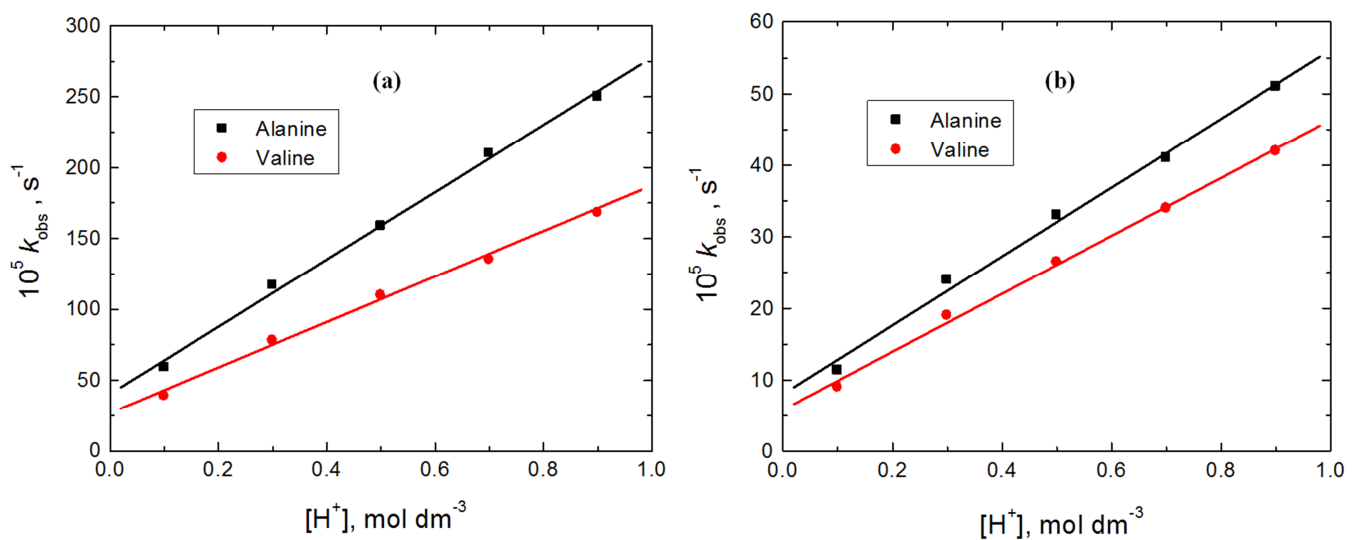

Figure 3. Plots of $\log k_{C}$ versus $\log \left[H^{+}\right]$in the silver (I)-catalyzed oxidations of alanine and valine by platinum (IV) in perchloric and sulfuric acids solutions. $[A A]=6.0 \times 10^{-3},\left[\mathrm{Pt}^{I V}\right]=8.0 \times 10^{-5},\left[\mathrm{Ag}^{I}\right]=1.0 \times 10^{-5}$ and $\mathrm{I}=1.0 \mathrm{~mol} \mathrm{dm} \mathrm{m}^{-3}$ at $25^{\circ} \mathrm{C}$. 

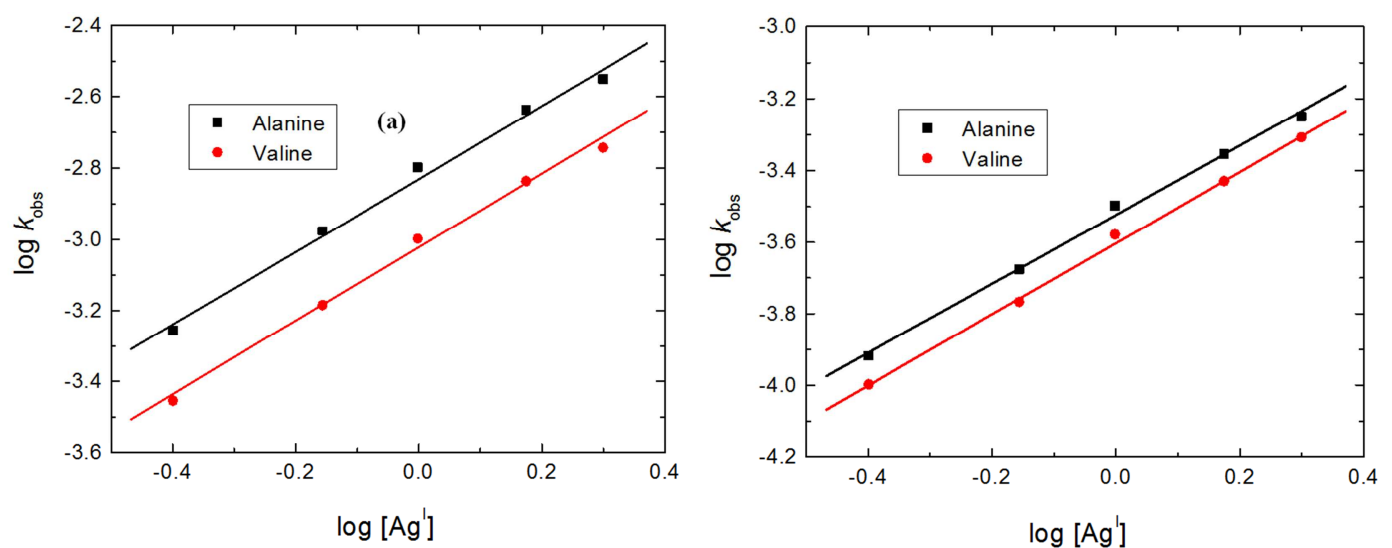

Figure 4. Plots of $\log k_{C}$ versus $\log \left[\mathrm{Ag}^{I}\right]$ in the silver (I)-catalyzed oxidations of alanine and valine by platinum(IV) in perchloric and sulfuric acids solutions. $[A A]=6.0 \times 10^{-3},\left[P^{I V}\right]=8.0 \times 10^{-5},\left[H^{+}\right]=0.5$ and $I=1.0 \mathrm{~mol} \mathrm{dm}^{-3}$ at $25^{\circ} \mathrm{C}$.
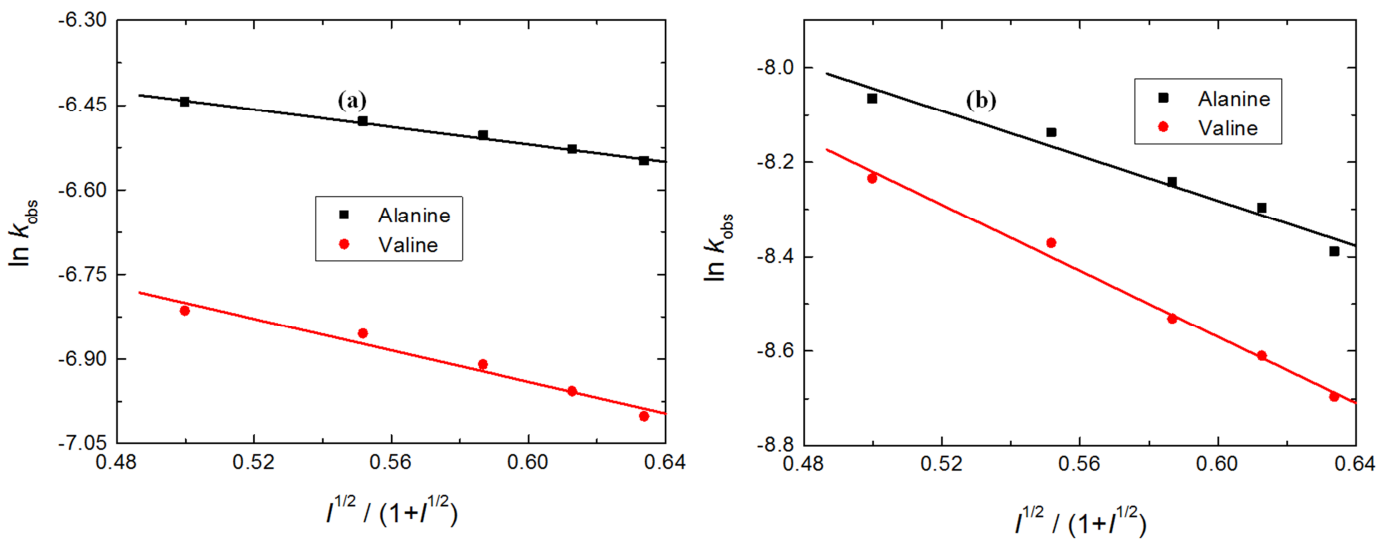

Figure 5. Debye-Hückel plots in the silver (I)-catalyzed oxidations of alanine and valine by platinum(IV) in perchloric and sulfuric acids solutions. [AA] $=$ $6.0 \times 10^{-3},\left[\mathrm{Pt}^{I V}\right]=8.0 \times 10^{-5},\left[\mathrm{H}^{+}\right]=0.5,\left[\mathrm{Ag}^{I}\right]=1.0 \times 10^{-5}$ and $I=1.0 \mathrm{~mol} \mathrm{dm} m^{-3}$ at $25^{\circ} \mathrm{C}$.

\subsection{Effect of Temperature}

The oxidation rates were performed at four different temperatures in the range of $288-318 \mathrm{~K}$, at constant concentrations of the reactants and other conditions being constant. The activation parameters of the second order rate constants $\left(k_{2}\right)$ are calculated using Arrhenius and Eyring plots and are listed in Table 2.

Table 2. Activation parameters of the second order rate constants $k_{2}$ inthe silver (I)-catalyzed oxidations of alanine and valine by platinum (IV) in perchloric and sulfuric acids solutions. $[\mathrm{AA}]=6.0 \times 10^{-3},\left[\mathrm{Pt}^{I V}\right]=8.0 \times 10^{-5}$, $\left[\mathrm{H}^{+}\right]=0.5,\left[\mathrm{Ag}^{I}\right]=1.0 \times 10^{-5}$ and $I=1.0 \mathrm{~mol} \mathrm{dm}^{-3}$.

\begin{tabular}{|c|c|c|c|c|c|}
\hline $\begin{array}{l}\text { Acid } \\
\text { medium }\end{array}$ & $\begin{array}{l}\text { Amino } \\
\text { acid }\end{array}$ & $\begin{array}{l}\Delta S^{\ddagger}, \mathbf{J} \\
\mathbf{m o l}^{-1} \mathbf{K}^{-1} \\
\end{array}$ & $\begin{array}{l}\Delta H^{\ddagger}, \mathrm{kJ} \\
\mathrm{mol}^{-1}\end{array}$ & $\begin{array}{l}\Delta G_{298}^{ \pm}, \mathrm{kJ} \\
\mathrm{mol}^{-1}\end{array}$ & $\begin{array}{l}E_{\mathrm{a}}^{\neq}, \mathrm{kJ} \\
\mathrm{mol}^{-1}\end{array}$ \\
\hline \multirow{2}{*}{ Perchloric } & Alanine & -102.13 & 37.02 & 67.45 & 39.81 \\
\hline & Valine & -97.05 & 41.14 & 70.06 & 42.87 \\
\hline \multirow{2}{*}{ Sulfuric } & Alanine & -98.11 & 43.51 & 72.75 & 43.91 \\
\hline & Valine & -107.43 & 45.07 & 77.08 & 44.07 \\
\hline
\end{tabular}

Experimental error $\pm 4 \%$

\subsection{Polymerization Test}

The involvement of free radicals in the oxidation reactions in both acids was examined by the polymerization test. The reactions mixtures to which a known quantity of acrylonitrile scavenger has been added initially and was kept in inert atmosphere for $4 \mathrm{~h}$. Upon diluting the reactions mixtures with methanol, there were no white precipitates formed, suggesting absence of free radicals intervention during the oxidation reactions. This indicates that the reactions were not routed through free radical path.

\section{Discussion}

It is also reported [36] that the platinum (IV) species in acid medium is present as $\left[\mathrm{PtCl}_{6}\right]^{2-}$, which is assumed to be the principal reactive oxidant. The reduction of $\left[\mathrm{PtCl}_{6}\right]^{2-}$ generally proceeds as follows:

$$
\left[\mathrm{PtCl}_{6}\right]^{2-}+2 \mathrm{e}^{-}=\left[\mathrm{PtCl}_{4}\right]^{2-}+2 \mathrm{Cl}^{-}
$$

In this reduction process, octahedral $\mathrm{Pt}^{\mathrm{IV}}$ is reduced to square planar $\mathrm{Pt}^{\mathrm{II}}$ with release of two $\mathrm{Cl}^{-}$ions. Therefore, this reaction is better classified as a reductive-elimination reaction [25, 26]. Because platinum (IV) complexes are generally substitution-inert [37], initial complex formation between platinum (IV) and reductant prior to electron transfer can be excluded in reductive-elimination reactions.

Two alternative reaction mechanisms for the oxidation of amino acids by platinum (IV) may be considered. The first mechanism involves a simultaneous two-electron transfer in 
a single step. The second mechanism involves two successive one-electron transfer steps. If the transition states of the reductant and/or oxidant are unstable, a simultaneous twoelectron transfer mechanism may be suggested, such as that in the oxidation of uranium (IV) by $\left[\mathrm{PtCl}_{6}\right]^{2-}[38]$. In the present study, addition of acrylonitrile monomer to the reaction mixture failed to give polymerized products. It may be that a free radical such as the $\mathrm{Pt}^{\mathrm{III}}$ species is too short-lived to interact with acrylonitrile to give the polymerized product under our experimental conditions. Consequently, the twoelectron transfer mechanism seems plausible.

The investigated reactions between $\alpha$-aminobutyric acid and platinum (IV) in both perchloric and sulfuric acids solutions have a 1:1 stoichiometry. The reactions exhibited a first order dependence with respect to both $\left[\mathrm{Pt}^{\mathrm{IV}}\right]$ and $\left[\mathrm{Ag}^{\mathrm{I}}\right]$, less than unit order dependences with respect to both [AA] and $\left[\mathrm{H}^{+}\right]$. The observed enhancement of the oxidation rates upon increasing acids concentration with the less than unit order dependences suggests [39] that the protonated forms of the amino acids may be considered as the kinetically reactive species in the rate-determining step, which play the main role in the reactions kinetics. The less than unit order dependences with respect to the concentrations of the amino acids suggests formation of intermediate complexes between amino acids and $\mathrm{Ag}^{\mathrm{I}}$ catalyst as reported earlier [17, 18, 21] owing to the availability of the electron pairs on both oxygen atom of the carboxylate group and nitrogen atom of the amine group in the amino acids. Within the protolytic amino acids systems, the carboxylate and amine groups may act as nucleophiles, depending on $\mathrm{pH}$ of the medium. The protolytic group with the highest basicity interacts with the silver (I) catalyst. Thus, at low $\mathrm{pH}$ where the amine group is protonated, the carboxylate group should be able to attack $\mathrm{Ag}^{\mathrm{I}}$. Complexes formation was proved kinetically by the positive intercepts of the linear plots of $\left[\mathrm{Ag}^{\mathrm{I}}\right] / k_{\mathrm{C}}$ versus $1 /$ [AA] (Figure 6). Spectroscopic evidence to support complexes formation was obtained from the UV-Vis spectra where hyposchromic shifts in the wavelength with the appearance of two isosbestic points as shown in Figure 1.

Based on the experimental results and the abovementioned arguments, the oxidation mechanism illustrated in Scheme 1 suggests that the protonated amino acid combines with $\mathrm{Ag}^{\mathrm{I}}$ to form an intermediate complex (C) which then reacts in a slow step with one mole of platinum (IV) to give rise to the products with regeneration of the catalyst $\mathrm{Ag}^{\mathrm{I}}$. The decrease in the oxidation rates upon increasing ionic strength of the reactions media suggests that the reactions in the ratedetermining step occur between two oppositely charged ions [40-42], i.e. between the positively charged complex and $\left[\mathrm{PtCl}_{6}\right]^{2-}$.<smiles>[Y]C=CC([R])C(=O)O</smiles>

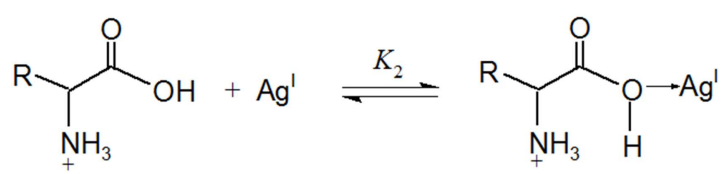

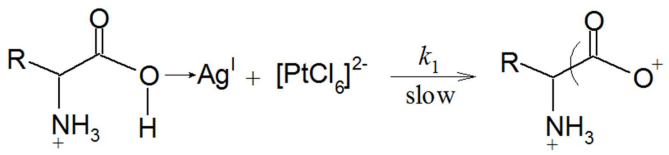

$$
\begin{aligned}
& +\left[\mathrm{PtCl}_{4}\right]^{2-}+2 \mathrm{Cl}^{-}+\mathrm{H}^{+}+\mathrm{Ag}^{\prime}
\end{aligned}
$$

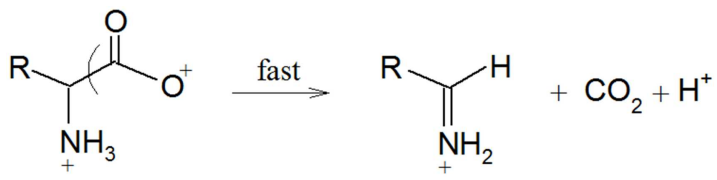

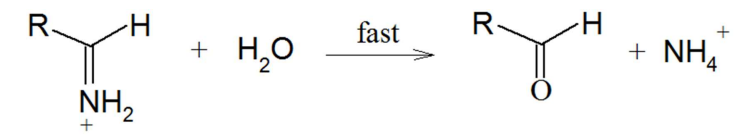

$\mathrm{R}=\mathrm{CH}_{3}$ for alanine, and $\mathrm{R}=\mathrm{CH}\left(\mathrm{CH}_{3}\right)_{2}$ for valine

Scheme 1. Mechanism of silver(I)-catalyzed oxidations of alanine and valine by platinum(IV) in acids solutions.

According to the suggested mechanistic Scheme 1,

$$
\begin{gathered}
\text { Rate } \frac{d\left[\mathrm{Pt}^{\mathrm{IV}}\right]}{d t} \quad k_{1}[\mathrm{C}]\left[\mathrm{Pt}^{\mathrm{IV}}\right] \\
K_{1} \frac{[\mathrm{AA}]}{[\mathrm{AA}][\mathrm{H}]} \\
\boldsymbol{K}_{2} \frac{[\mathrm{AA}]}{[\mathrm{AA}]\left[\mathrm{Ag}^{\mathrm{I}}\right]} \frac{K_{1}[\mathrm{AA}]\left[\mathrm{H}^{+}\right]}{\boldsymbol{K}_{1}[\mathrm{AA}][\mathrm{H}]\left[\mathrm{Ag}^{\mathrm{I}}\right]} \\
{[\mathrm{C}]=K_{1} K_{2}[\mathrm{AA}]\left[\mathrm{H}^{+}\right]\left[\mathrm{Ag}^{\mathrm{I}}\right]}
\end{gathered}
$$

Substituting Eq. (10) into Eq. (6) yields,

$$
\text { Rate }=k_{1} K_{1} K_{2}[\mathrm{AA}]\left[\mathrm{H}^{+}\right]\left[\mathrm{Ag}^{\mathrm{I}}\right]\left[\mathrm{Pt}^{\mathrm{IV}}\right]
$$

The total concentration of the amino acid is given by,

$$
[\mathrm{AA}]_{\mathrm{T}}=[\mathrm{AA}]_{\mathrm{F}}+\left[\mathrm{AA}^{+}\right]+[\mathrm{C}]
$$

where $[\mathrm{AA}]_{\mathrm{T}}$ and $[\mathrm{AA}]_{\mathrm{F}}$ stand for total and free concentrations of the amino acids, respectively.

Substituting Eqs. (8) and (10) into Eq. (12) gives,

$$
\begin{gathered}
{[\mathrm{AA}]_{\mathrm{T}}=[\mathrm{AA}]_{\mathrm{F}}+K_{1}[\mathrm{AA}]_{\mathrm{F}}\left[\mathrm{H}^{+}\right]+K_{1} K_{2}[\mathrm{AA}]_{\mathrm{F}}\left[\mathrm{H}^{+}\right]\left[\mathrm{Ag}^{\mathrm{I}}\right]} \\
{[\mathrm{AA}]_{\mathrm{T}}=[\mathrm{AA}]_{\mathrm{F}}\left(1+K_{1}\left[\mathrm{H}^{+}\right]+K_{1} K_{2}\left[\mathrm{H}^{+}\right]\left[\mathrm{Ag}^{\mathrm{I}}\right]\right)} \\
{[\mathrm{AA}]_{\mathrm{F}}=\frac{[\mathrm{AA}]_{\mathrm{T}}}{1+K_{1}\left[\mathrm{H}^{+}\right]+K_{1} K_{2}\left[\mathrm{H}^{+}\right]\left[\mathrm{Ag}^{\mathrm{I}}\right]}} \\
{\left[\mathrm{Ag}^{\mathrm{I}}\right]_{\mathrm{T}}=\left[\mathrm{Ag}^{\mathrm{I}}\right]_{\mathrm{F}}+[\mathrm{C}]}
\end{gathered}
$$

Substituting Eq. (8) into Eq. (10) and rearranging gives, 


$$
\left[\mathrm{Ag}^{\mathrm{I}}\right]_{\mathrm{F}}=\frac{\left[\mathrm{Ag}^{\mathrm{I}}\right]_{\mathrm{T}}}{1+K_{1} K_{2}[\mathrm{AA}]\left[\mathrm{H}^{+}\right]}
$$

In view of high $\left[\mathrm{H}^{+}\right]$,

$$
\left[\mathrm{H}^{+}\right]_{\mathrm{T}}=\left[\mathrm{H}^{+}\right]_{\mathrm{F}}
$$

In addition,

$$
\left[\mathrm{Pt}^{\mathrm{IV}}\right]_{\mathrm{T}}=\left[\mathrm{Pt}^{\mathrm{IV}}\right]_{\mathrm{F}}
$$

Substituting Eqs. (15), (17)- (19) into Eq. (11) (and omitting ' $T$ ' and ' $F$ ' subscripts) gives,

$$
\text { Rate }=\frac{k_{1} K_{1} K_{2}[\mathrm{AA}]\left[\mathrm{H}^{+}\right]\left[\mathrm{Ag}^{\mathrm{I}}\right]\left[\mathrm{Pt}^{\mathrm{tV}}\right]}{\left(1+K_{1}\left[\mathrm{H}^{+}\right]+K_{1} K_{2}\left[\mathrm{H}^{+}\right]\left[\mathrm{Ag}^{\mathrm{I}}\right]\right)\left(1+K_{1} K_{2}[\mathrm{AA}]\left[\mathrm{H}^{+}\right]\right)}
$$

In view of low $\left[\mathrm{Ag}^{\mathrm{I}}\right]$ used, the term $K_{1} K_{2}\left[\mathrm{H}^{+}\right]\left[\mathrm{Ag}^{\mathrm{I}}\right]$ in the denominator of Eq. (20) can be neglected. Therefore, Eq. (20) becomes,

$$
\text { Rate }=\frac{k_{1} K_{1} K_{2}[\mathrm{AA}]\left[\mathrm{H}^{+}\right]\left[\mathrm{Ag}^{\mathrm{I}}\right]\left[\mathrm{Pt}^{\mathrm{IV}}\right]}{\left(1+K_{1}\left[\mathrm{H}^{+}\right]\right)\left(1+K_{1} K_{2}[\mathrm{AA}]\left[\mathrm{H}^{+}\right]\right)}
$$

Under pseudo-first-order conditions, the rate law can be expressed as,

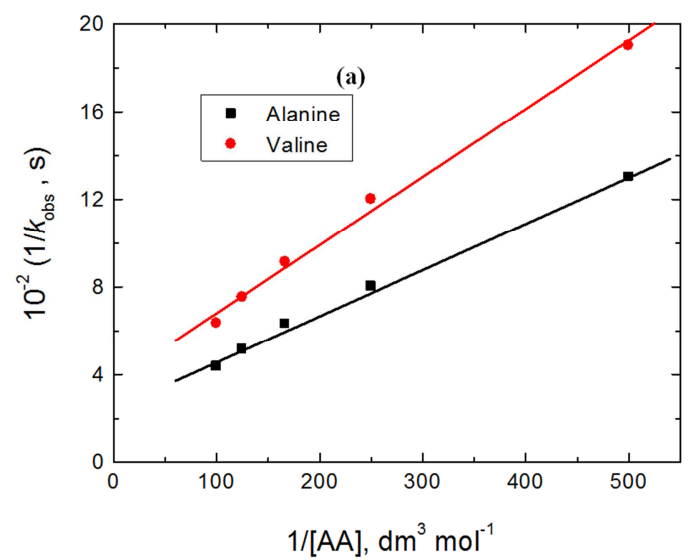

$$
\text { Rate }=\frac{-d\left[\mathrm{Pt}^{\mathrm{IV}}\right]}{d t}=k_{C}\left[\mathrm{Pt}^{\mathrm{IV}}\right]
$$

Comparing Eqs. (21) and (22), the following relationship is obtained,

$$
k_{C}=\frac{k_{1} K_{1} K_{2}[\mathrm{AA}]\left[\mathrm{H}^{+}\right]\left[\mathrm{Ag}^{\mathrm{I}}\right]}{\left(1+K_{1}\left[\mathrm{H}^{+}\right]\right)\left(1+K_{1} K_{2}[\mathrm{AA}]\left[\mathrm{H}^{+}\right]\right)}
$$

and with rearrangement it becomes,

$$
\begin{gathered}
\frac{\left[\mathrm{Ag}^{\mathrm{I}}\right]}{k_{\mathrm{C}}}=\left(\frac{1+K_{1}\left[\mathrm{H}^{+}\right]}{k_{1} K_{1} K_{2}\left[\mathrm{H}^{+}\right]}\right) \frac{1}{[\mathrm{AA}]}+K^{\prime} \\
\frac{\left[\mathrm{Ag}^{\mathrm{I}}\right]}{k_{\mathrm{C}}} \frac{1}{k_{1} K_{1} K_{2}[\mathrm{AA}]} \frac{1}{[\mathrm{H}]} \frac{1}{k_{1} \boldsymbol{K}_{2}[\mathrm{AA}]} K^{\prime}
\end{gathered}
$$

Where $K^{\prime}=\left(1+K_{1}\left[\mathrm{H}^{+}\right]\right) / k_{1}$.

According to equations (24) and (25), the plots of $\left[\mathrm{Ag}^{\mathrm{I}}\right] /$ $k_{\mathrm{C}}$ against $1 /[\mathrm{AA}]$, at constant $\left[\mathrm{H}^{+}\right]$, and $\left[\mathrm{Ag}^{\mathrm{I}}\right] / k_{\mathrm{C}}$ against $1 /\left[\mathrm{H}^{+}\right]$, at constant $[\mathrm{AA}]$, should be linear with positive intercepts on $\left[\mathrm{Ag}^{\mathrm{I}}\right] / k_{\mathrm{C}}$ axes. The experimental results satisfied this requirement as shown in Figures 6 and 7, respectively.

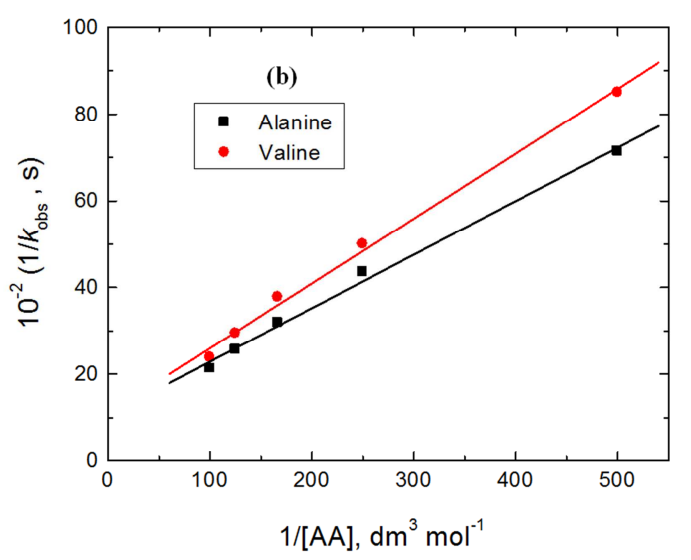

Figure 6. Verification of equation (24) in the silver (I)-catalyzed oxidations of alanine and valine by platinum (IV) in perchloric and sulfuric acids solutions. $\left[P t^{I V}\right]=8.0 \times 10^{-5},\left[\mathrm{H}^{+}\right]=0.5$ and $\mathrm{I}=1.0 \mathrm{~mol} \mathrm{dm}{ }^{-3}$ at $25^{\circ} \mathrm{C}$.
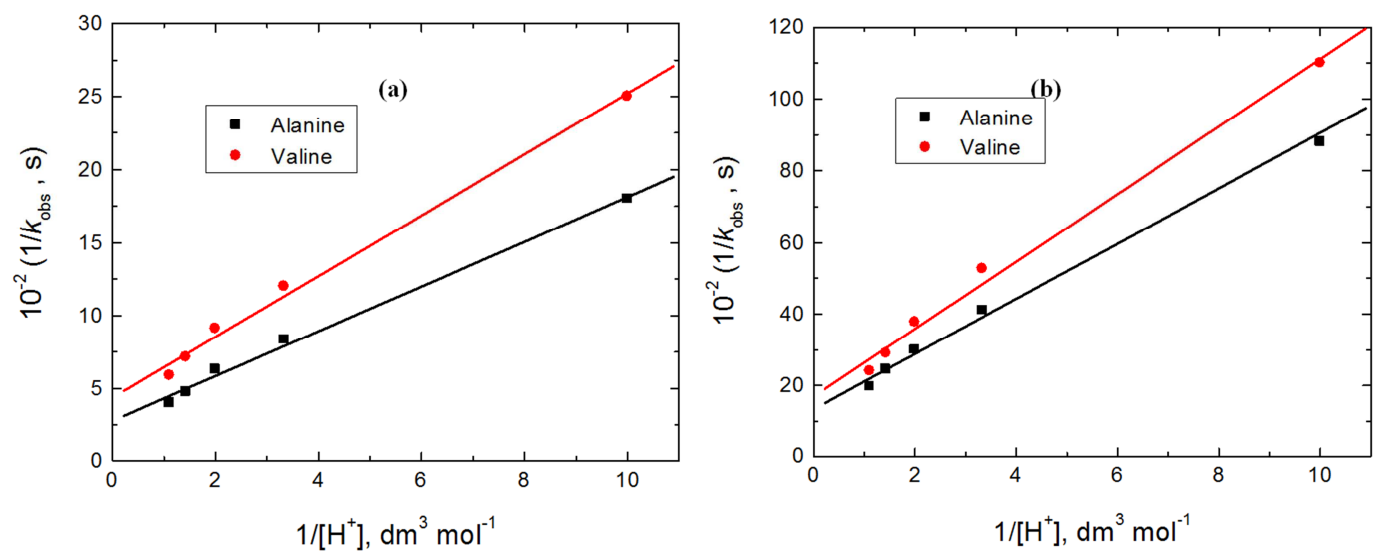

Figure 7. Verification of equation (25) in the silver (I)-catalyzed oxidations of alanine and valine by platinum (IV) in perchloric and sulfuric acids solutions. $[A A]=6.0 \times 10^{-3},\left[\mathrm{Pt}^{I V}\right]=8.0 \times 10^{-5}$ and $\mathrm{I}=1.0 \mathrm{~mol} \mathrm{dm}^{-3}$ at $25^{\circ} \mathrm{C}$. 
The activation parameters listed in Table 2 may be interpreted as follows. The obtained negative values of $\Delta S^{\neq}$ suggest that the reactions point towards the inner-sphere pathway [43]. The positive values of both $\Delta H^{\neq}$and $\Delta G^{f}$ confirm endothermic formation of the intermediate complexes and their non-spontaneities, respectively.

\section{Conclusion}

The kinetics of oxidations of alanine and valine by platinum (IV) has been investigated in perchloric and sulfuric acids solutions in the presence of silver (I) catalyst. The reactions were very slow to be measured in the absence of the catalyst. Under comparable experimental conditions, the oxidation rates of alanine and valine in perchloric acid solutions were found to be about five times higher than those obtained in sulfuric acid solutions and the oxidation rates of alanine in both acids were found to be higher than those recorded with respect to valine. A plausible oxidations mechanism has been proposed. The oxidation products of the amino acids were identified as the corresponding aldehyde, ammonium ion and carbon dioxide.

\section{References}

[1] Sumathi T, Sundaram PS, Chandramohan G (2011) A kinetic and mechanistic study on the silver (I)-catalyzed oxidation of L-alanine by cerium (IV) in sulfuric acid medium. Arab J. Chem. 4: 427-435.

[2] Hassan RM (1991) Kinetics and mechanism of oxidation of DL-a-alanine by permanganate ion in acid perchlorate media. J. Chem. 69: 2018-2023.

[3] Singh R, Tamta DK, Joshi SK, Chandra N, Kandpal ND (2011) Oxidation of amino acids by manganese (III) in aqueous sulphuric acid. J. Chem. Pharm. Res. 3: 529-535.

[4] Devra V, Jain S, Sharma PD (1994) Kinetics and mechanism of oxidation of glycine, alanine, and threonine by fluoride coordinated bismuth (V) in aqueous $\mathrm{HClO}_{4}-\mathrm{HF}$ medium. Int. J. Chem. Kinet. 26: 577-585.

[5] Pérez - benito JF, Rodriguez RM, De Andrés G, Brillas E, Garrido JA (2012) Kinetics and mechanisms of the permanganate oxidation of $\mathrm{L}$ - valine in neutral aqueous solutions. Int. J. Chemi. Kinet. 21:71-81.

[6] Sharanabasamma K, Angadi MA, Salunke MS, Tuwar S (2012) Kinetics of oxidation of L-valine by a copper (III) periodate complex in alkaline medium. J. Solution Chem. 41: 187-199.

[7] Chidan Kumar CS, Chandraju S, Made Gowda NM (2012) Oxidation of L-valine by manganese (III) in pyrophosphate medium: kinetics and mechanism. Am. J. Org. Chem. 2: 2125 .

[8] Criado S, Marioli JM, Allegretti PE, Furlong J, Rodríguez Nieto FJ, Mártire DO, García NA (2001) Oxidation of di- and tripeptides of tyrosine and valine mediated by singlet molecular oxygen, phosphate radicals and sulfate radicals. J Photochem Photobiol B. 65: 74-84.
[9] Fawzy A, Ashour SS, Musleh MA, Hassan RM, Asghar BH (2015) Kinetics and mechanistic approach to the chromic acid oxidation of L-tryptophan with a spectral detection of chromium (III) product. J. Saudi Chem. Soc. in press.

[10] Sanjeevagowda TP, Mahantesh AA, Abdulazizkhan LH (2008) Oxidative deamination and decarboxylation of Lasparagine by the aqueous alkaline diperiodato-nickelate (IV) complex. J. Solution Chem. 37: 1795-180.

[11] Khalid MAA (2007) Oxidative kinetics of amino acids by peroxydisulfate: Effect of dielectric constant, Arabian J. Sci. Eng. 33: 199-210.

[12] Senagar SKS, Yadav BS (1988) Kinetics and mechanism of copper (II)-catalyzed oxidation of asparagine by sodium Nchloro-p-toluene sulphonamide in alkaline media. J. Indian Chem. Soc. 65: 88-90.

[13] Asghar BH, Altass HM, Fawzy A (2015) Copper (II) catalysis for oxidation of L-tryptophan by hexacyanoferrate (III) in alkaline medium: a kinetic and mechanistic approach. J. Saudi. Chem. Soc. in press.

[14] Fawzy A (2015) Palladium (II)-catalyzed oxidation of Ltryptophan by hexacyanoferrate (III) in perchloric acid medium: a kinetic and mechanistic approach. J. Chem. Sci. In press.

[15] Fawzy A (2014) Influence of copper (II) catalyst on the oxidation of L-histidine by platinum (IV) in alkaline medium: a kinetic and mechanistic study. Transition Met. Chem. 39: 567-576.

[16] Fawzy A (2015) Kinetics and mechanistic approach to the oxidative behavior of biological anticancer platinum (IV) complex towards L-asparagine in acid medium and the effect of copper (II) catalyst. Int. J. Chem. Kinet. 47: 1-12.

[17] Fawzy A, Asghar BH (2015) Kinetics and mechanism of uncatalyzed and silver (I)-catalyzed oxidation of L-histidine by hexachloroplatinate (IV) in acid medium. Transition Met. Chem. 40: 287-295.

[18] Asghar BH, Altass HM, Fawzy A (2015) Transition metal ions-catalyzed oxidation of L-asparagine by platinum (IV) in acid medium: a kinetic and mechanistic study. Transition Met. Chem. 40: 587-594.

[19] Fawzy A, Zaafarany IA (2015) Kinetic and mechanistic investigation on the zirconium (IV)-catalyzed oxidation of Lhistidine by hexachloroplatinate (IV) in acid medium. Chem. Sci. Rev. Lett. 4: 608-618.

[20] Fawzy A, Zaafarany IA (2015) Mechanistic investigation of copper (II)-catalyzed oxidation of L-asparagine by hexachloroplatinate (IV) in aqueous alkaline medium: a kinetic approach. J. Multidisc. Eng. Sci. Technol. 2: 1038-1045.

[21] Asghar BH, Altass HM, Fawzy A (2016) Silver (I)-catalysis of oxidative deamination and decarboxylation of L-asparagine and L-histidine by platinum (IV) in perchloric acid solutions: a comparative kinetics study. J. Env. Chem. Eng. 4: 617-623.

[22] Fawzy A, Ashour SS, Musleh MA (2014) Base-catalyzed oxidation of L-asparagine by alkaline permanganate and the effect of alkali-metal ion catalysts: Kinetics and mechanistic approach, React. Kinet. Mech. Catal. 111: 443-460.

[23] Fawzy A, Ashour SS, Musleh MA (2014) Kinetics and mechanism of oxidation of L-histidine by permanganate ions in sulfuric acid medium, Int. J. Chem. Kinet. 46: 370-381. 
[24] Keage MC, Kelland MJ, Neidles LR, Warning MJ, ed. (1993) Molecular Aspects of Anticover Drug DNA Interactions, vol. 1, CRC Press, New York, NY, USA.

[25] Lemma K, Sargeson A, Elding LI (2000) Kinetics and mechanism for reduction of oral anticancer platinum (IV) dicarboxylate compounds by L-ascorbate ions. J. Chem. Soc. Dalton Trans. 7: 1167-1172.

[26] Lemma K, Shi T, Elding LI (2000) Kinetics and mechanism for reduction of the anticancer prodrug trans, trans, trans$\left[\mathrm{PtCl}_{2}(\mathrm{OH})_{2}\left(\mathrm{c}-\mathrm{C}_{6} \mathrm{H}_{11} \mathrm{NH}_{2}\right)\left(\mathrm{NH}_{3}\right)\right](\mathrm{JM} 335)$ by thiols. Inorg. Chem. 39: 1728-1734.

[27] Weiss RP, Christian MC (1993) New cisplatin analogues in development. A review. Drugs 46: 360-377.

[28] Beattie K, Basolo F (1967) Reduction of some platinum (IV) complexes with tris (bipyridine) chromium (II) ion. Inorg. Chem. 6: 2069-2073.

[29] Beattie K, Basolo F (1971) Two-electron inner-sphere reduction of chloropentaammine-platinum (IV) ion by aquochromium (II) ion. Inorg. Chem. 10: 486-491.

[30] Moodley KG, Nicol MJ (1977) Kinetics of the reduction of platinum (IV) by tin (II) and copper (I) in aqueous chloride solutions. J. Chem. Soc., Dalton Trans. 239-243.

[31] Pal B, Sen Gupta KK (2000) Kinetics and mechanism of hexachloroplatinate (IV) reduction by some neutralized alphahydroxy acids in a carbonate-hydrogencarbonate buffer medium, Bull. Chem. Soc. Jpn. 73: 553-560.

[32] Shukla R, Upadhyay SK (2008) Non-ionic micellar inhibition on the rate of oxidation of L-histidine by alkaline hexacyanoferrate (III). Indian J. Chem. 47A: 551-555.
[33] Georgieva M, Andonovski B (2003) Determination of platinum (IV) by UV spectrophotometry. Anal. Bioanal. Chem. 375: 836-839.

[34] Vogel AI (1973) Text book of practical organic chemistry, third ed., ELBS Longman, London, 1973, pp. 332 and 679.

[35] Feigl F (1975) Spot tests in organic analysis, 195 pp. Elsevier, New York.

[36] Kramer J, Koch KR (2006) ${ }^{195}$ Pt NMR Study of the speciation and preferential extraction of $\mathrm{Pt}$ (IV)-mixed halide complexes by diethylenetriamine-modified silica-based anion exchangers. Inorg. Chem. 45: 7843-7855.

[37] Mason WR (1972) Platinum (II)-catalyzed substitutions of platinum (IV) complexes. Coord. Chem. Rev.7: 241-255.

[38] Hassan RM, Kojima T, Fukutomi T (1982) Kinetics of the oxidation of uranium (IV) by hexachloroplatinate (IV) in aqueous solution. VI International symposium on solutesolute-solvent interactions. Japan, pp. 113.

[39] Martell AE, Smith RM (1974) In: Critical Stability Constants. vol. I. Plenum Press, New York, pp. 321.

[40] Amis ES (1966) Solvent Effect on Reaction Rates and Mechanism, Academic Press, New York, pp. 28.

[41] Frost AA, Person RG (1970) Kinetics and mechanism, Wiley Eastern, New Delhi, pp. 147.

[42] Laidler K (1965) Chemical Kinetics. McGraw-Hill, New York.

[43] Weissberger A (1974) In Investigation of rates and mechanism of reactions in techniques of chemistry, John Wiley \& Sons (New York: Interscience Publication) pp. 421. 